Diabetologia 11, 279-284 (1975)

(C) by Springer-Verlag 1975

\title{
The Effects of Glucose, N-Acetylglucosamine, Glyceraldehyde and Other Sugars on Insulin Release in Vivo
}

\author{
S.J.H. Ashcroft and J.R. Crossley \\ Department of Biochemistry, University of Bristol, England
}

Received: February 18, 1975, and in revised form: April 28, 1975

\begin{abstract}
Summary. The specificity for carbohydrates of insulin secretory responses in vivo was studied. Test sugars were injected via a left femoral vein cannula into conscious rats. Blood samples collected over the ensuing $60 \mathrm{~min}$ via a left femoral arterial cannula were assayed for plasma insulin and glucose, and, in some experiments, for $\mathrm{N}$-acetyl glucosamine. Whereas L-glucose or saline produced no significant changes in plasma insulin or glucose concentrations, D-glucose, $\mathrm{N}$-acetylglucosamine, D-glucosamine, fructose, D-glyceraldehyde and DL-glyceraldehyde were potent secretagogues. Simultaneous injection of mannoheptulose abolished the insulinotropic action of glucose and $\mathrm{N}$-acetylglucosamine, but not of $\mathrm{DL}$ glyceraldehyde. Fructose, glucosamine, and DL-glyceraldehyde in-
\end{abstract}

duced hyperglycaemia, but peak insulin concentrations occurred before any change in plasma glucose concentration. No evidence was obtained for a stimulatory effect of galactose on insulin release. Infusion for $60 \mathrm{~min}$ of $\mathrm{N}$-acetylglucosamine produced a sustained elevated plasma insulin concentration and significant hypoglycaemia. The present in vivo results agree with previous in vitro observations, and could indicate a role for sugars other than glucose in the regulation of insulin release.

Key words: $\mathrm{N}$-acetylglucosamine, insulin release, glyceraldehyde, glucose, glucosamine, fructose, galactose, mannoheptulose, glucoreceptor.
Detailed studies of the specificity of the insulin secretory response to sugars have been performed with mouse and rat islets of Langerhans in vitro $[1,2]$. Of a large number of sugars tested only glucose, mannose, glyceraldehyde and, to a small extent, glucosamine have been shown to initiate insulin release when tested singly at a concentration of $20 \mathrm{mM}$ in the presence of caffeine. A second group of sugars were ineffective alone, but in the presence of an initiator such as glucose or D-glyceraldehyde elicited a marked increase in insulin release rate: these potentiators of release were fructose $[1,2,4], \mathrm{N}$-acetylglucosamine $[1,2]$, L-glyceraldehyde [3] and (in the rat islets only) galactose [1]. These findings were interpreted in terms of a two-site glucoreceptor model [2]. On this model the glucoreceptor is envisaged to possess two different classes of sub-units: an initiator unit sensitive to glucose, mannose, glyceraldehyde and glucosamine (or a metabolite thereof), and a potentiator unit of broader specificity. Binding at the potentiator site only elicits insulin release if at the same time the initiator site is activated; then, via co-operative interaction between the units, a faster rate of insulin release occurs than in the absence of potentiator. Whether the initiator site responds directly to glucose (and other initiators) or to metabolites thereof formed within the B-cell has not been conclusively established. Strong evidence for the involvement of a metabolite has been provided by the close correlations observed between the metabolic activities of exogeneous substrates and their ability to initiate insulin release in isolated mouse islets $[1,2]$. In addition the specificity of the inhibitory action of mannoheptulose is that which would be predicted for a metabolic basis for initiation: i.e. mannoheptulose inhibits the metabolism of glucose but not of glyceraldehyde, and blocks glucose - stimulated but not glyceraldehyde-stimulated release $[2,3]$.

Much less information is available on the specificity in vivo of the insulin secretory response to sugars. Results of previous in vivo studies have been reviewed [5]. However early investigations (e.g. 6) did not have the benefit of the sensitive and specific insulin radioimmunoassay, and later studies (e.g. 7) have been confined to a more restricted range of sugars. We report below the results of an investigation to establish whether the spectrum of secretory responses observed in vitro is applicable to the in vivo situation. We have tested the effects of intravenous injection of initiators and potentiators of insulin release and of mannoheptulose on plasma insulin concentrations in overnight - fasted conscious rats. 


\section{Material and Methods}

\section{Sugars}

All test sugars (D-glucose, L-glucose, N-acetyl-Dglucosamine, D-fructose, D-galactose, D-mannoheptulose, $\mathrm{D}$-glucosamine $\mathrm{HCl}$ ) were of the purest grade commercially available. Glucosamine $\mathrm{HCl}$ was converted to free glucosamine by shaking with triethylamine/ethanol. Since the D-glyceraldehyde (Sigma, G-4876) contained $30 \%$ of an unidentified impurity DL-glyceraldehyde (British Drug Houses) was used for most experiments. Similar results were obtained with both sugars. Solutions for injection $(1 \mathrm{ml})$ were prepared in sterile saline immediately prior to use.

\section{Animals}

Male albino Wistar rats $(230-280 \mathrm{~g})$ were used throughout. Rats were allowed free access to food and water prior to surgery. Cannulae (2FG, Portex, Kent, England) were inserted into the left femoral vein and artery under Nembutal anaesthesia, secured by surgical thread, and kept patent with saline containing 160 $\mathrm{U} / \mathrm{ml}$ heparin [8]. After recovery the animals were kept in restraining cages overnight, with food withheld but free access to water.

Test substances were injected into the femoral vein; nine arterial blood samples $(0.35 \mathrm{ml})$ were collected at the times stated in the figures and tables and immediately chilled in ice. The plasma separated by centrifugation was assayed immediately or stored frozen. In one series of experiments, the femoral vein cannula was connected to a peristaltic pump (Pharmacia). $\mathrm{N}$-acetylglucosamine $\left(1 \times 10^{-3}\right.$ moles $)$ was injected through a sideport, and then infused for $60 \mathrm{~min}$ at a rate of $2.4 \times 10^{-5}$ moles $(40 \mu \mathrm{l})$ per minute.

A few animals which had been tested with glucose or saline alone, were used for a second experiment, two hours after completion of the first. No significant difference in plasma glucose or insulin concentration (expressed relative to that at time zero for each experiment) was found when consecutive identical time courses were performed with glucose, indicating that the secretory responses were not affected by the reduction in blood volume.

\section{Assay of Plasma Insulin}

Plasma insulin concentrations were measured by radioimmunoassay essentially as described by Albano et al. [9]. The assay buffer reagent diluent was $0.05 \mathrm{M}$ sodium phosphate $\mathrm{pH} 7.4$ containing $0.1 \%$ $\mathrm{w} / \mathrm{v}$ bovine albumin (Frn V) and $6 \times 10^{-3} \mathrm{M}$ mer- thiolate. Rat insulin standard (Lot 170) was a gift from Dr. A.J..Moody of the Novo Research Institute, Copenhagen, Denmark. ${ }^{125} \mathrm{I}$-insulin $(50 \mu \mathrm{Ci} / \mu \mathrm{g})$ was purchased from the Radiochemical Centre, Amersham. Guinea pig antibovine insulin serum was prepared in this laboratory. Insulin-free rat plasma was added to each tube not containing a test plasma sample. The incubation volume was $0.2 \mathrm{ml}$; usually $20 \mu \mathrm{l}$ of plasma was assayed in triplicate. "Free" and antibody-bound hormone were separated by addition of albumin-coated charcoal $(1 \mathrm{ml} 0.6 \% \mathrm{w} / \mathrm{v}$ Norit GSX charcoal in diluent containing $0.4 \%, \mathrm{w} / \mathrm{v}$ bovine albumin). The tubes were centrifuged, the supernatant removed by suction and discarded, and the ${ }^{125} \mathrm{I}$ associated with the charcoal pellet measured using a solid well-type gamma radiation counter. Insulin concentrations were evaluated using a computer programme based on the function described by Täljedal and Wold [11].

\section{Assay of Plasma Sugars}

Plasma glucose concentrations were measured by the glucose oxidase method [12]. Plasma N-acetylglucosamine concentrations were measured by two methods. One of these utilised $\mathrm{N}$-acetylglucosamine kinase prepared from rat liver by the method of Saeki et al. [13]. $5 \mu \mathrm{l}$ plasma was added to $1.5 \mathrm{ml} 150 \mathrm{ml}$ TRA $\mathrm{pH} 7.5$ containing $10 \mathrm{mM} \mathrm{MgCl}_{2}, 6 \mathrm{mM}$ ATP, $5 \mathrm{mM}$ phosphoenolpyruvate, $0.1 \mathrm{mM} \mathrm{NADH}, 1 \mathrm{U} / \mathrm{ml}$ pyruvate kinase, $1 \mathrm{U} / \mathrm{ml}$ lactate dehydrogenase and a suitable volume of $\mathrm{N}$-acetylglucosamine kinase. The oxidation of NADH was measured by adsorption at 340 $\mathrm{nm}$. Glucose was not a substrate for $\mathrm{N}$-acetyl-glucosamine kinase. No $\mathrm{N}$-acetylglucosamine could be detected in normal plasma samples. A chemical assay of $\mathrm{N}$-acetylglucosamine [14] gave similar results.

\section{Calculation of Results}

In each experiment the plasma insulin and glucose concentrations at time zero for each rat were substracted from the values at the other time points. The mean changes in glucose $(\Delta G)$ and insulin $(\Delta I)$ $( \pm$ S.E.M.) for each test substance are plotted against time.

\section{Results}

The mean arterial plasma glucose and insulin concentrations at time zero in these experiments were $5.3 \pm 0.1 \mathrm{mM}$ and $19 \pm 1.4 \mu \mathrm{U} / \mathrm{ml}$ respectively (mean \pm S.E.M.; $n=72$ ). In control experiments in which rats received injections of saline or L-glucose $\left(1.4 \times 10^{-3}\right.$ moles $)$ the changes in plasma insulin and 
Table 1. Changes in plasma insulin $(\Delta I)$ and glucose $(\Delta G)$ concentrations in response to intravenous injection at zero minutes of $D$-galactose, $D$-fructose or D-glucosamine. Results are given as mean $\pm S . E . M$. for the number of experiments stated

\begin{tabular}{|c|c|c|c|c|c|c|}
\hline \multicolumn{7}{|c|}{ Monosaccharide injected $\left(1.4 \times 10^{-3}\right.$ moles $)$} \\
\hline \multirow{3}{*}{$\begin{array}{l}\text { Time } \\
\text { (mins) }\end{array}$} & \multicolumn{2}{|l|}{ D-Galactose } & \multicolumn{2}{|l|}{ D-Fructose } & \multicolumn{2}{|l|}{ D-Glucosamine } \\
\hline & $\Delta \mathrm{G}(\mathrm{mM})$ & $\Delta \mathrm{I}(\mu \mathrm{U} / \mathrm{ml})$ & $\Delta \mathrm{G}(\mathrm{mM})$ & $\Delta \mathrm{I}(\mu \mathrm{U} / \mathrm{ml})$ & $\Delta \mathrm{G}(\mathrm{mM})$ & $\Delta \mathrm{I}(\mu \mathrm{U} / \mathrm{ml})$ \\
\hline & \multicolumn{2}{|c|}{$\mathrm{n}=4$} & \multicolumn{2}{|c|}{$\mathbf{n}=4$} & \multicolumn{2}{|c|}{$\mathrm{n}=5$} \\
\hline-10 & $0.31 \pm 0.22$ & $-4.4 \pm 2.0$ & $-0.56 \pm 0.44$ & $-5.0 \pm 6.0$ & $-0.17 \pm 0.22$ & $-3.0 \pm 1.5$ \\
\hline 0 & 0 & 0 & 0 & 0 & 0 & 0 \\
\hline 1 & $0.53 \pm 0.06^{\mathrm{b}}$ & $21 \pm 3.5^{b}$ & $-0.28 \pm 0.17$ & $239 \pm 38^{\mathrm{b}}$ & $-0.39 \pm 0.28$ & $0 \pm 3.0$ \\
\hline 2.5 & $0.71 \pm 0.29$ & $11 \pm 4.0$ & $-0.22 \pm 0.17$ & $136 \pm 5.0^{\mathrm{c}}$ & $0 \pm 0.37$ & $67 \pm 16^{a}$ \\
\hline 5 & $0.83 \pm 0.40$ & $6.5 \pm 2.5$ & $1.3 \pm 0.11^{\mathrm{b}}$ & $67 \pm 8.5^{\mathrm{b}}$ & $0.56 \pm 0.17^{\mathrm{a}}$ & $29 \pm 15$ \\
\hline 10 & $1.0 \pm 0.32$ & $9.0 \pm 2.5^{\mathrm{a}}$ & $3.7 \pm 0.39^{\mathrm{b}}$ & $53 \pm 19^{a}$ & $1.3 \pm 0.39^{\mathrm{a}}$ & $-3.5 \pm 3.0$ \\
\hline 20 & $1.1 \pm 0.16^{\mathrm{b}}$ & $18 \pm 5.0^{\mathrm{a}}$ & $4.2 \pm 0.61^{b}$ & $48 \pm 13^{\mathrm{a}}$ & $2.4 \pm 0.33^{b}$ & $-2.0 \pm 3.0$ \\
\hline 40 & $1.3 \pm 0.14^{\mathrm{b}}$ & $7.0 \pm 7.5$ & $2.6 \pm 0.56^{\mathrm{a}}$ & $37 \pm 17$ & $5.2 \pm 0.56^{\mathrm{b}}$ & $0 \pm 3.5$ \\
\hline 60 & $2.2 \pm 0.29^{\mathrm{b}}$ & $8.5 \pm 5.5$ & $2.1 \pm 0.89^{\mathrm{a}}$ & $22 \pm 20$ & $6.9 \pm 0.83^{\mathrm{c}}$ & $6.0 \pm 4.0$ \\
\hline
\end{tabular}

${ }^{\mathrm{a}} p<0.05 ;{ }^{\mathrm{b}} p<0.01 ;{ }^{\mathrm{c}} p<0.001$

Table 2. Changes in insulin $(\Delta I)$ and glucose $(\Delta G)$ concentrations in response to intravenous injection at zero minutes of $D$ - or DL glyceraldehyde alone or with D-mannoheptulose. Results are given as mean $\pm S$. E.M. for the number of experiments stated

\section{Substance injected}

\begin{tabular}{|c|c|c|c|c|c|c|c|c|}
\hline \multirow[t]{3}{*}{$\begin{array}{l}\text { Time } \\
\text { (mins) }\end{array}$} & \multicolumn{2}{|c|}{$\begin{array}{l}\text { D-glyceraldehyde } \\
\left(5 \times 10^{-4} \text { moles }\right)\end{array}$} & \multicolumn{2}{|c|}{$\begin{array}{l}\text { DL-glyceraldehyde } \\
\left(5 \times 10^{-4} \text { moles }\right)\end{array}$} & \multicolumn{2}{|c|}{$\begin{array}{l}\text { DL-glyceraldehyde } \\
\left(1.4 \times 10^{-3} \text { moles }\right)\end{array}$} & \multicolumn{2}{|c|}{$\begin{array}{l}\text { DL-glyceraldehyde } \\
\left(1.4 \times 10^{-3} \text { moles }\right) \\
\text { plus } \mathrm{D} \text {-mannoheptulose } \\
\left(1.5 \times 10^{-3} \text { moles }\right)\end{array}$} \\
\hline & $\Delta \mathrm{G}(\mathrm{mM})$ & $\Delta \mathrm{I}(\mu \mathrm{U} / \mathrm{ml})$ & $\Delta \mathrm{G}(\mathrm{mM})$ & $\Delta \mathrm{I}(\mu \mathrm{U} / \mathrm{ml})$ & $\Delta \mathrm{G}(\mathrm{mM})$ & $\Delta \mathrm{I}(\mu \mathrm{U} / \mathrm{ml})$ & $\Delta \mathrm{G}(\mathrm{mM})$ & $\Delta \mathrm{I}(\mu \mathrm{U} / \mathrm{ml})$ \\
\hline & \multicolumn{2}{|c|}{$\mathrm{n}=3$} & \multicolumn{2}{|c|}{$\mathrm{n}=3$} & \multicolumn{2}{|c|}{$\mathrm{n}=3$} & \multicolumn{2}{|c|}{$\mathrm{n}=5$} \\
\hline-10 & $-0.29 \pm 0.02$ & $\begin{array}{r}-10 \pm 0.5 \\
0\end{array}$ & $\begin{array}{l}0.06 \pm 0.61 \\
0\end{array}$ & $\begin{array}{l}0.5 \pm 2.5 \\
0\end{array}$ & $\begin{array}{l}0.50 \pm 0.67 \\
0\end{array}$ & $\begin{array}{c}-4.5 \pm 3.0 \\
0\end{array}$ & $2.9 \pm 0.11^{\mathrm{b}}$ & $-14.0 \pm 3.0$ \\
\hline $\begin{array}{l}0 \\
1\end{array}$ & $0.07 \pm 0.14$ & $180 \pm 35^{\mathrm{a}}$ & $0.06 \pm 0.17$ & $175 \pm 15^{\mathrm{b}}$ & $0.06 \pm 0.39$ & $189 \pm 14^{\mathrm{b}}$ & $0.06 \pm 0.06$ & $67 \pm 23^{a}$ \\
\hline 2 & $0.44 \pm 0.21$ & $114 \pm 12.5^{\mathrm{a}}$ & $0.11 \pm 0.06$ & $60 \pm 4.5^{\mathrm{b}}$ & $0 \pm 0.39$ & $151 \pm 21^{\mathrm{a}}$ & $0.44 \pm 0.06$ & $9.5 \pm 2.5^{\mathrm{a}}$ \\
\hline 5 & $0.09 \pm 0.15$ & $6.5 \pm 7.5$ & $0.17 \pm 0.17$ & $-4.0 \pm 4.0$ & $1.2 \pm 0.33$ & $73 \pm 13^{\mathrm{a}}$ & $0.94 \pm 0.17^{\mathrm{b}}$ & $-5.0 \pm 1.5^{\mathrm{a}}$ \\
\hline 10 & $0.09 \pm 0.21$ & $-14 \pm 6.0$ & $0.56 \pm 0.17$ & $-12 \pm 6.0$ & $3.3 \pm 0.50^{\mathrm{a}}$ & $24 \pm 7.0$ & $2.4 \pm 0.33^{b}$ & $-11 \pm 3.5^{\mathrm{a}}$ \\
\hline 20 & $0.46 \pm 0.07^{\mathrm{a}}$ & $-11 \pm 6.5$ & $1.3 \pm 0.44$ & $0.5 \pm 7.0$ & $4.3 \pm 0.72^{\mathrm{a}}$ & $4.0 \pm 8.5$ & $3.8 \pm 0.39^{c}$ & $-33.5 \pm 3.0^{b}$ \\
\hline 40 & $0.43 \pm 0.21$ & $-10 \pm 5.5$ & $1.1 \pm 0.50$ & $-2.0 \pm 2.0$ & $4.9 \pm 0.89^{\mathrm{a}}$ & $23 \pm 8.5$ & $5.7 \pm 0.33^{c}$ & $-15 \pm 2.5^{b}$ \\
\hline 60 & $0.83 \pm 0.37$ & $-6.0 \pm 5.0$ & $0.94 \pm 0.61$ & $-2.5 \pm 4.0$ & $5.3 \pm 0.72^{\mathrm{a}}$ & $33 \pm 14$ & $6.5 \pm 0.33^{\mathrm{c}}$ & $-10 \pm 4$ \\
\hline
\end{tabular}

${ }^{\mathrm{a}} p<0.05 ;{ }^{\mathrm{b}} P<0.01 ;{ }^{\mathrm{c}} p<0.001$

glucose concentration were not statistically significant (with the exception of a small increase in plasma insulin at time $60 \mathrm{~min}$ after L-glucose).

The effects of injection of glucose $\left(7 \times 10^{-5}-1.4\right.$ $\times 10^{-3}$ moles) are shown in Fig. 1. Peak insulin concentrations were observed $1 \mathrm{~min}$ after injection, and there was a graded response to increasing glucose dose.

The effect of glucose $\left(5 \times 10^{-4}\right.$ moles $)$ was totally abolished by simultaneous administration of mannoheptulose $\left(1.5 \times 10^{-3}\right.$ moles $)$ and plasma glucose concentrations remained elevated for $60 \mathrm{~min}$. With the exception of the highest dose of glucose, plasma insulin concentrations were restored to basal by 60 mins.

The effects of fructose and galactose are given in Table 1. Fructose $\left(1.4 \times 10^{-3}\right.$ moles $)$ administration produced a rapid rise in plasma insulin and also hyperglycemia. However the peak rise in insulin occurred before any change in plasma glucose i.e. within the first $2.5 \mathrm{~min}$ after injection. Galactose $\left(1.4 \times 10^{-3}\right.$ moles) administration, however had only a very small effect on plasma insulin concentration; moreover the possibility could not be excluded that the observed 

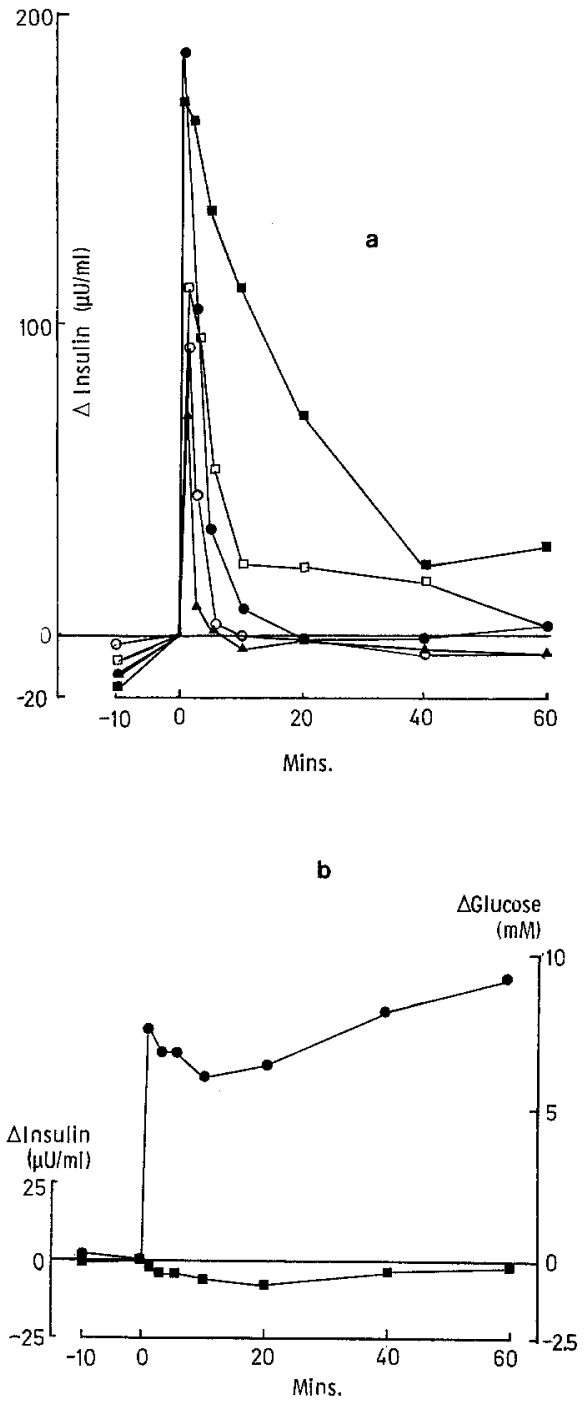

Fig. 1. Effect of glucose and mannoheptulose on plasma insulin concentration. Panel (a) shows the changes in plasma insulin concentrations after intravenous injection at zero minutes of $1.4 \times 10^{-3}$ (四); $0.7 \times 10^{-3}(\square) ; 0.3 \times 10^{-3}$ (F11); $1.5 \times 10^{-4}$ (O) and $0.7 \times 10^{-4}(\mathbf{A})$ moles glucose. Panel (b) shows that simultaneous injection of $0.5 \times 10^{-3}$ moles glucose and $1.5 \times 10^{-3}$ moles mannoheptulose caused no increase in plasma insulin concentration ( $)$ despite elevated blood glucose concentrations $(\bullet)$. The data are mean values for $3-5$ experiments in panel (a) and for 2 experiments in panel (b)

change in insulin was attributable to the small but significant $(P<0.05)$ elevation in plasma glucose at time $1 \mathrm{~min}$. Hence no evidence for a direct effect of galactose on insulin release is provided by these data.

The effects of glucosamine $\left(1.4 \times 10^{-3}\right.$ moles $)$ are also given in Table 1. Marked elevation of plasma insulin concentration occurred over the first $5 \mathrm{~min}$ after glucosamine injection without change in plasma 


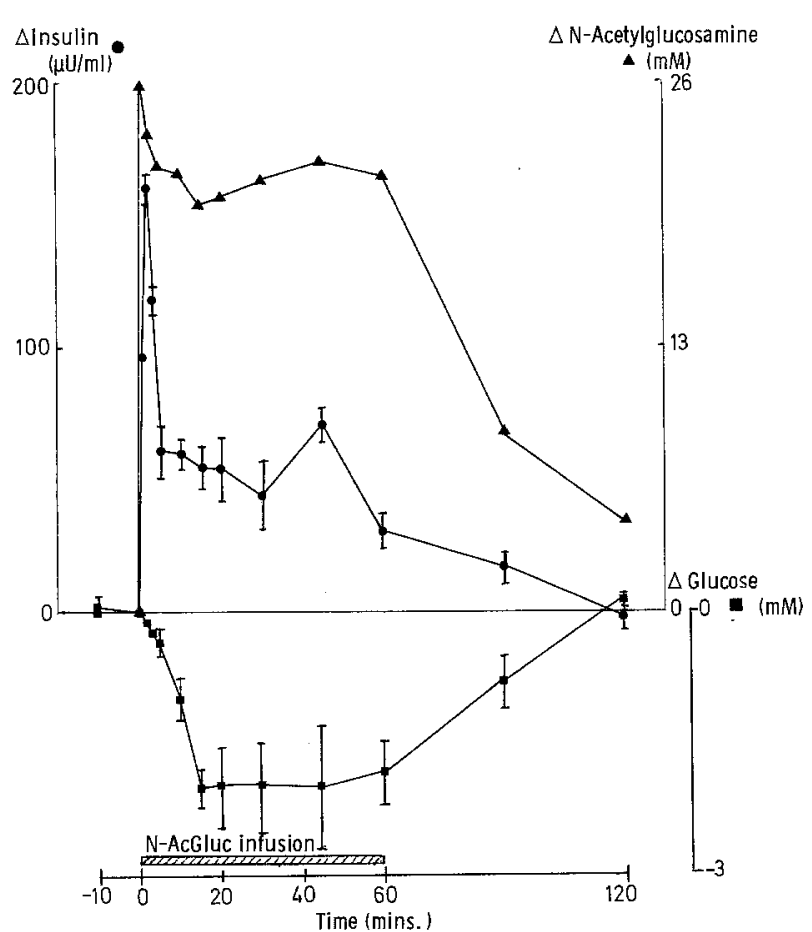

Fig. 2. Changes in plasma insulin (F11), glucose ( $\mathbf{0})$ and N-acetylglucosamine $(\mathbf{A})$ concentrations after injection at time zero of $1 \times 10^{-3}$ moles $\mathrm{N}$-acetylglucosamine followed by infusion of $\mathrm{N}$-acetylglucosamine $\left(2.4 \times 10^{-5} \mathrm{moles} / \mathrm{min}\right.$ from time zero to $60 \mathrm{~min}$. The data are mean values of 3 experiments

glucose concentrations. Subsequently hyperglycemia occurred without change in plasma insulin concentration. With this dose, the response was consistently delayed; no increase occurred in plasma insulin until $2.5 \mathrm{~min}$ after injection. With a lower dose of glucosamine, peak plasma insulin concentration was achieved at $1 \mathrm{~min}$ after injection. (results not shown).

Table 2 shows that $5 \times 10^{-4}$ moles D-glyceraldehyde elicited a rapid and marked rise in plasma insulin without significant change in plasma glucose concentration. Plasma insulin concentration returned to basal $5 \mathrm{~min}$ after D-glyceraldehyde injection. DL-glyceraidehyde was also insulinogenic: the response to $5 \times 10^{-4}$ moles DL-glyceraldehyde was similar to that with D-glyceraldehyde. A larger dose of DL-glyceraldehyde $\left(1.4 \times 10^{-3}\right.$ moles $)$ was hyperglycemic but the peak insulin concentration occurred before any change in plasma glucose concentration. The insulin secretion induced by $5 \times 10^{-4}$ moles DL-glyceraldehyde was not abolished by the simultaneous administration of $1.5 \times 10^{-3}$ moles mannoheptulose although the peak insulin concentration achieved was lowered (one animal which failed to respond to glyceraldehyde and mannoheptulose has been excluded from these data).

The insulin secretory response to injection of $\mathrm{N}$ -
acetyl-D-glucosamine is given in Table 3. N-acetylglucosamine was a potent insulin releasing agent; this effect was not mediated by conversion to glucose since plasma glucose concentrations were consistently lowered following $\mathrm{N}$-acetyl-glucosamine. There was a graded secretory response to injection of $\mathrm{N}$-acetylglucosamine $\left(1.7 \times 10^{-4}-1.4 \times 10^{-3}\right.$ moles $)$ and the response was totally abolished by mannoheptulose. Plasma $\mathrm{N}$-acetylglucosamine concentrations following $\mathrm{N}$-acetylglucosamine injection are also given in Table 3; plasma $\mathrm{N}$-acetylglucosamine had returned to basal (i. e. undetectable) $60 \mathrm{~min}$ after injection. The effect on insulin release and blood glucose of maintaining a raised plasma $\mathrm{N}$-acetylglucosamine concentration by infusion is shown in Fig. 2. Insulin concentration, after an immediate peak, remained elevated until the end of the infusion of $\mathrm{N}$-acetylglucosamine and a marked lowering of blood glucose concentration was observed.

\section{Discussion}

Previous studies have established the specificity of insulin secretory responses to sugars in vitro $[1,2]$. The present results provide strong evidence that a similar pattern of responses may exist in the more complex in vivo situation. Thus plasma insulin concentrations were rapidly increased by D-glucose, (but not by L-glucose), by glucosamine and by glyceraldehyde, previously shown to be initiators of insulin release in vitro $[1,2,3]$. Mannoheptulose abolished the effect of glucose on insulin release but not that of glyceraldehyde, as in vitro $[2,3]$. A dual action of glucosamine on insulin release has been described in vitro i.e. glucosamine itself stimulated insulin release, albeit weakly, but inhibited glucose - stimulated insulin release [2]. The kinetics of these effects have not been reported. The present study shows that, at a physiological glucose concentration, glucosamine rapidly increased insulin release; subsequently however, despite hyperglycemia, insulin levels remained at a basal level, suggesting that the inhibitory effect of glucosamine predominates after the first few minutes.

Fructose and $\mathrm{N}$-acetylglucosamine potentiated insulin release in vitro in the presence of sub-stimulatory glucose concentrations $[1,2,4]$, and both sugars are shown here to produce marked and rapid increases in plasma insulin concentrations in vivo. The initial secretory response to fructose injection may be a direct effect of fructose on the B-cell: from $5 \mathrm{~min}$ after fructose injection pronounced hyperglycemia occurs which itself will influence insulin release. The strong effect of $\mathrm{N}$-acetylglucosamine cannot be attributed to 
its conversion to glucose; plasma glucose levels show indeed a tendency to decrease slightly after $\mathrm{N}$-acetylglucosamine injection, presumably in response to the hyperinsulinemia. That hypoglycemia is not more marked despite the hyperinsulinaemia may perhaps indicate some interference by $\mathrm{N}$-acetylglucosamine with peripheral or hepatic glucose metabolism. However when $\mathrm{N}$-acetylglucosamine was infused to maintain a constant blood concentration of about $20 \mathrm{mM}$, marked hypoglycemia was observed. It is also of interest that the $\mathrm{N}$-acetylglucosamine tolerance curves are similar to equimolar glucose tolerance curves; whether insulin increases $\mathrm{N}$-acetylglucosamine utilization is not known. Mannoheptulose abolished the effect of $\mathrm{N}$-acetylglucosamine in vivo as it has been shown to do in vitro [2].

It was not possible with the present technique to demonstrate a direct effect of galactose on insulin release. Although injection of $1.4 \times 10^{-3}$ moles galactose elicited a small but significant increase in plasma insulin this might have been caused by the small but significant rise in plasma glucose. Morever the magnitude of the observed insulin response was close to the limits of the method, as assessed in control animals.

Although clearly with an in vivo study the presence of plasma glucose precludes differentiation between initiators and potentiators of insulin release, the present results are in good overall agreement with in vitro observations. That the highly specific insulin secretory response should extend to the naturally occurring glucosamine and $\mathrm{N}$-acetylglucosamine (indeed the latter appears at least as potent as glucose, in vivo) could indicate a role for these sugars in the regulation of insulin release. Isolated islets have been shown to be capable of metabolising glucosamine and $\mathrm{N}$-acetylglucosamine [2]; extracts of rat islets contain $\mathrm{N}$-acetylglucosamine kinase (unpublishedobservations). However under what circumstances, if any, these sugars are available to the B-cell is not known.

Acknowledgements. The authors gratefully thank Prof. K. G.M.M. Alberti and Dr. Paul Holloway, Southampton General Hospital for instruction in the surgical techniques, Dr. Paul England for writing the computer programme for insulin immunoassay, and Mrs. R. Rawson for skilled technical assistance. These studies were supported by grants from the British Diabetic Association, the British Insulin Manufacturers and the Medical Research Council.
Dr. Crossley is the recipient of a New Zealand University Grants Committee Post-doctoral Fellowship, and a New Zealand Medical Research Council Travel Grant.

\section{References}

1. Ashcroft, S. J.H., Bassett, J.M., Randle, P.J.: Insulin secretion mechanisms and glucose metabolism in isolated islets. Diabetes 21, Suppl. 2, 538-545 (1972)

2. Ashcroft, S.J.H., Weerasinghe, L.C.C., Randle, P.J.: Interrelationship of islet metabolism, adenosine triphosphate content and insulin release. Biochem. J. 132, 223-231 (1973)

3. Hellman, B., Idahl, L.- $\AA$., Sehlin, J., Täljedal, I.-B.: The pancreatic $\beta$-cell recognition of insulin secretagogues. Comparisons of glucose with glyceraldehyde isomers and dihydroxyacetone. Arch. Biochem. 162, 448-457 (1974)

4. Curry, D. L.: Fructose potentiation of mannose-induced insulin secretion. Amer. J. Physiol. 226, 1073-1076 (1974)

5. Pfeiffer, E.F., Ziegler, R.: In: Handbuch des Diabetes Mellitus. (ed. E.F.Pfeiffer), Vol. 1, p.221. Lehmanns Verlag, München, 1969

6. Pozza, G., Galansino, G., Hoffeld, H., Foa, P.P.: Stimulation of insulin output by monosaccharides and monosaccharide derivatives. Amer. J. Physiol. 192, 497-500 (1958)

7. Karam, J.H., Grasso, S.G., Wegienka, L. C., Grodsky, G.M., Forsham, P.H.: Effect of selected hexoses, of epinephrine and of glucagon on insulin secretion in man. Diabetes 15, 571-78 (1966)

8. Aynsley-Green, A., Biebuyck, J.F., Alberti, K.G. M.M.: Anaesthesia and Insulin Secretion: the effects of diethyl ether, halothane, pentobarbitone sodium and ketamine hydrochloride on intravenous glucose tolerance and insulin secretion in the rat. Diabetologia 9, 274-281 (1973)

9. Albano, J.D.M., Ekins, R.P., Maritz, G., Turner, R.C.: A sensitive precise radioimmunoassay of serum insulin relying on charcoal separation of bound and free hormone moieties. Acta. endocr. 70, 487-509 (1972)

10. Hales, C. N., Randle, P. J.: Immunoassay of insulin with insulinantibody precipitate. Biochem. J. 88, 137-137 (1963)

11. Täljedal, I.-B., Wold, S.: Fit of some analytic functions to insulin radioimmunoassay standard curves. Biochem. J. 119, $139-143(1970)$

12. Huggett, A.St.G., Nixon, D.A.: Enzymic determination of blood glucose. Biochem. J. 66, 12P (1957)

13. Saeki, H., Suzuki, R., Tsuiki, S.: Purification and properties of $\mathrm{N}$-acetylglucosamine kinase from rat liver. Tohoku J. exp. Med. 105, 87-88 (1971)

14. Reissig, J.L., Strominger, J.L., Leloir, L.F.: A modified colorimetric method for the estimation of $\mathrm{N}$-acetylamino sugars. J. biol. Chem. 217, 959-966 (1955)

Dr. S. J. H. Asheroft

Dept. of Biochemistry

Medical School

Univ. Walk

Univ. of Bristol

Bristol. BS8 1 TD

England 